\title{
USING LIVE PROJECTS IN AN INFORMATION SYSTEMS CAPSTONE COURSE
}

\author{
Lisa L. Kovalchick, California University of Pennsylvania, kovalchick@calu.edu \\ Gina M. Boff, California University of Pennsylvania, boff@calu.edu \\ Paul J. Kovacs, Robert Morris University,kovacs@rmu.edu
}

\begin{abstract}
The capstone course in a Computer Information Systems program provides an excellent opportunity for students to learn skills that will make them more competitive in the marketplace. Unlike the traditional textbook/lecture approach, using a live project can motivate the students to do additional work, illustrate to the students the value of the material covered and, most importantly, provide practical experiences that enrich the student's academic experiences. This paper conducted a survey of faculty from Computer Information Systems programs across the United States to determine use of live projects in a Computer Information Systems capstone course. This study addresses the following research questions: 1) Do most schools use "live" projects in their capstone course?, 2) How are capstone courses that use "live" projects tanght?, 3)If you use "live" projects in your capstone course, how do you solicit local companies' involvement?
\end{abstract}

Keywords: Capstone Course, Senior Project, Project-based Learning and CIS Curriculum.

\section{INTRODUCTION}

Referred to as the "Finishing Course" [4], the "Keystone" [8] and the "Senior Projects" [5], to name a few, the senior project capstone course in Information Systems is typically a two-semester series wherein students are "provided the opportunity to synthesize, analyze and apply knowledge acquired over several years" to a real-world business problem [12]. An excellent source for service learning [7], student groups become engaged in the study and analysis of a client business area, where they are charged with identifying functional business process issues that have the potential for improvement/resolution via the development and implementation of a customized computer software application or computer information system [2,5].

"The idea of including a capstone course in a degree program is, of course, not new. The value of a capstone course for a degree program (such as BSBA) has been evaluated, tried and generally recommended $[13,11]$ as cited in [4]. "Students that learn to successfully synthesize, analyze and apply knowledge in a capstone course gain an advantage in the highly competitive IS marketplace, leading to successful careers in the IS field" [12]. Authors Keller, Chan and Parker purport that "discipline knowledge alone is not sufficient for today's graduates to obtain employment" [10]. They go on to explain that communication, collaborative teamwork, negotiation, conflict resolution, selfmanagement and a number of other "generic skills" are critical to have, not only to ensure the success of the individual in industry, but they explain the ways in which the success of today's technological projects hinges on team members' generic skills [10]. Author Wright, in his article entitled "Capstone Programming Courses Considered Harmful" goes so far as to imply that a capstone course that focuses strictly on the programming aspect of a project will, in the long run, harm the student, as it skews his/her job expectations and associated ability to obtain related employment. If that hurdle were not to be overcome, the student, in the long run, will not be able to excel in the workforce [18]. While the projects are more complex requiring a longer duration than those required in prerequisite course work, the senior project capstone series is more than a technological proving ground. It is the complexity, duration and dynamic of the project which allow the students their first and only opportunity to apply their set of critical, generic skills over an extended period of time [10].

Authors Fordham, Bryand and Benke [8] expound on the need to stress "hybrid expertise" in the capstone learning experience, as their market research shows a stark shortage in IS professionals who are proficient in systems 


\section{Issues in Information Systems}

Volume 14, Issue 2, pp.149-155, 2013

development and design and the integration of technology with business disciplines. Authors Kumar and Ahmed [12] agree and go on to state that this hybrid IT-Business expertise "enables students to develop skills that they can use immediately to contribute to the organizations that hire them" [14] as cited in [12]. The capstone should contain a strong, multi-disciplinary component and a strong element of soft-skill or generic-skill focus in its assessment [10].

\section{VALUE ADDED}

The value added from an experiential capstone course is more far-reaching than the benefits and advantages gained by students. Following are some examples of the diversity of benefits a senior project capstone course series can offer:

The Community - Students are often required to explore not-for-profit organizations or small, family-owned companies within the local community. These types of organizations normally do not have the means to seek the type of service and product the capstone projects can deliver. While the students gain the unique experience of exploring a systems solution from the ground up and the organization benefits from the end-product, it can be a small boost to the local economy as well [7].

Faculty - While teaching a capstone course series poses many diverse challenges to the professor, it also provides opportunity in the role of a moderator and facilitator that doesn't often present itself in other CIS-related courses [4]. Inquisitive students tend to explore and bring to the table cutting-edge technological concepts that faculty may not have had the time or means to previously explore, allowing them continuous learning opportunities.

Administrators - A measureable benefit from the nature of the capstone construct is a curriculum perfectly designed to lend itself to Outcomes assessment [17]. Not only is this normally a regional, university requirement, but most reputable CIS-related programs will require an accreditation from a national accrediting agency which bases the award of accreditation on outcomes assessment [1].

The Program and University - Success stories from both successful graduates having gone through the capstone course and related program, and the satisfaction of past clients goes a long way in the marketing and recruitment for the program [12].

Both predictable and unexpected benefits resonate for many parties involved in capstone project courses, making a brief exploration of the epistemological background and structure of capstone courses, in order.

\section{LEARNING THEORIES}

The strength of the capstone experience stems from two, predominant underpinnings. First, is the constructivist school of learning on which the course work is designed and developed; the second is the resource-based learning model applied in the course itself. Both of these are briefly discussed.

While constructivist theory has roots dating to the days of Socrates (400 B.C.), most recognize John Dewey (1850's) as the father of its practical application through his active laboratory learning environment [6]. "According to the constructivist approach, learning is achieved through the establishment of correlations between previous knowledge in the mind and new knowledge and by internalizing new knowledge" [3]. Virtually all literature that addresses the construction and development of a capstone course series describes the integrative nature of the coursework that culminates to create the construct of the capstone course $[17,2,5]$.

Resource-based learning involves examining a topic and utilizing information from various resources to answer questions or solve problems related to the topic; these resources could include print and non-print media such as books, video recordings, electronic databases, etc. [15]. Unlike traditional learning, in resource-based learning, the teacher and textbook are not the major providers of information, but rather, the teacher is a facilitator to assist in the discovery of information from various resources. Students must learn to search for the information needed to 


\section{Issues in Information Systems}

Volume 14, Issue 2, pp.149-155, 2013

answer questions and solve problems; nowadays, the Internet is widely utilized to gather such resources. The information obtained must be critically analyzed in order to ensure its validity and usefulness. Finally, the information obtained is applied to the question or problem in order to build a solution.

Hand-in-hand with constructivism is the migration from traditional learning to resource-based learning as the student advances in their coursework. The following table contrasts traditional learning from resource-based learning:

Table 1. Traditional Learning versus Resource-Based Learning (Reinicke, Janicki, 2010; orig. Rakes, 1996).

\begin{tabular}{|l|l|}
\hline Traditional Learning & Resource-Based Learning \\
\hline Teacher as an expert model & Teacher as a facilitator/guide \\
\hline Textbook as primary source & Variety of sources/media \\
\hline Facts as primary & Questions as primary \\
\hline Information is packaged & Information is discovered \\
\hline Emphasis on product & Emphasis on process \\
\hline Assessment is quantitative & Assessment is qualitative/quantitative \\
\hline
\end{tabular}

Here, we can see the traditional model is better employed as the introductory levels of coursework, where information is packaged and delivered to the student. Over time, there should be a natural progression through the curriculum into the mode of resource-based learning, where the student actively seeks the information, assesses and applies it and then is able to internalize the knowledge gained. This, in turn, is built upon again and again and is, by definition, constructivist theory. It is the marriage of these two learning theories that make a capstone course series such a powerful educational tool.

\section{THE MISSING LINK}

Reports, treatise and university case studies abound describing the curriculum integration needed and the makeup of the course content in capstone courses [17]. Authors discuss strategies to align with business, the need to keep coursework up to date and those effects on the capstone course and the assistance to be gained from vendor academic initiatives $[9,12]$. Student preparation, faculty preparation and facility preparation necessary to facilitate the capstone courses is reported, even the capstone experience as related to outsourcing and the concept of the experience launching the stages of grief as students adjust $[5,4,12]$. Project phases, activities, artifacts used, group make up and selection processes are all discussed $[5,10 ; 12]$. What is not covered - what is not mentioned - is what comprises the most difficult components to senior project capstone courses:

From where do the projects come? What techniques are used to motivate students to perform at their best? To not procrastinate so as to conduct adequate user-acceptance and quality assurance testing, end-user training and some degree of system support with final fixes/modifications? One set of authors introduces the idea of their department working with the "community and alumnae who are working in the field to help students choose real-world projects", but little to no reports of the aforementioned issues with senior project capstones is found [2]. It is this missing link that these authors hope to find.

This study focuses on the "live" projects themselves. It examines the number of institutions using "live" projects versus those using "non-live" projects. It examines how a course using "live" projects is taught, that is, how long is the course (in semesters), who normally teaches the course, how many students are typically assigned to a group and the availability of a designated budget for the course. Finally, it examines the process used to solicit projects.

\section{METHODS AND PROCEDURES}


The current research involved the administration of a paper survey instrument that consisted of 12 questions. This survey was administered at various computer information systems conferences throughout the United States, during the academic years of 2010 to 2013, to computing faculty at various colleges and universities. At each conference, the survey was administered after a presentation on capstone learning; the audience was given the survey and asked to complete it. In order to avoid duplicate survey responses from a single university program, if there were multiple people in the audience from a single university program, they were asked to work together to complete a single survey. A total of 30 survey responses were anonymously collected and the results were analyzed.

\section{REARCH RESULTS}

\section{Research Question 1}

In order to answer the first research question (Do most schools use "live" projects in there capstone course?), the survey instrument posed the following questions.

- Does your institution offer a capstone course?

- Do you use "live" projects; that is, do you have real-world clients/problems/companies that work with your students to design and implement solutions?

Every survey respondent answered "yes" to the question "Does your institution offer a capstone course?" This is not surprising, since the survey instrument was distributed to the audience following a presentation on capstone learning.

The results from the question "Do you use "live" projects; that is, do you have real-world clients/problems/companies that work with your students to design and implement solutions?" are summarized in Figure 1.

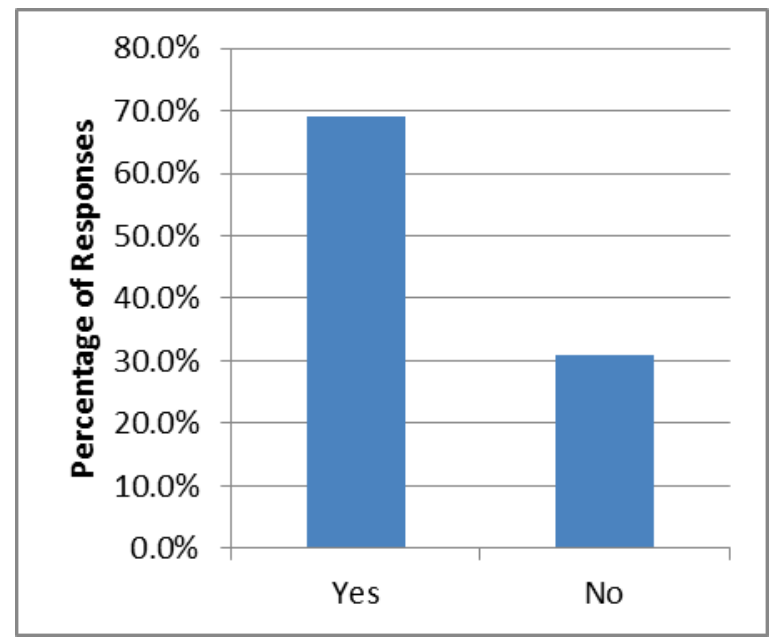

Figure 1. Results from the question: "Do you use "live" projects?

As shown in Figure 1, an overwhelming majority of respondents (69\%) indicated that "live" projects are used in the capstone course at their institution. Therefore, it seems that most institutions recognize the benefits of the use of "live" projects in a capstone course.

\section{Research Question 2}


In order to answer the second research question (How are capstone courses, that use "live" projects, taught?), the survey instrument posed the following questions.

- Do you use "live" projects; that is, do you have real-world clients/problems/companies that work with your students to design and implement solutions?

- How long is the course (in semesters)?

- Which best describes the way the course is taught?

- How many students are typically assigned to a given project?

- Is there a designated budget for the course(s)?

In order to answer this research question, the results from the latter 4 questions were cross-tabulated with the first question. The results of the courses that use "live" projects are summarized in Table 2.

Table 2. How are capstone courses, that use "live" projects, taught?

\begin{tabular}{|l|c|c|}
\hline \multicolumn{1}{|l|}{ How long is the course (in semesters)? } & & \\
1 semester & 17 & $85.0 \%$ \\
2 semesters & 3 & $15.0 \%$ \\
$>2$ semesters & 0 & $0.0 \%$ \\
\hline & & \\
How is the course taught? & & \\
Always taught by the same professor & 11 & $52.4 \%$ \\
Rotated among a few professors & 8 & $38.1 \%$ \\
Rotated among all computing faculty & 2 & $9.5 \%$ \\
Team taught & 0 & $0.0 \%$ \\
Other & 0 & $0.0 \%$ \\
\hline Number of students typically assigned to & & \\
a given project & & \\
Projects are individual & 2 & $7.7 \%$ \\
2 -3 students & 4 & $15.4 \%$ \\
4 - 5 students & 14 & $53.8 \%$ \\
6 - 10 students & 3 & $11.5 \%$ \\
$>10$ students & 1 & $3.8 \%$ \\
Entire class & 2 & $7.7 \%$ \\
\hline Is there a budget for the course? & & \\
Yes & 3 & $15.0 \%$ \\
No & 17 & $85.0 \%$ \\
\hline
\end{tabular}

It is important to note that, since this was a paper survey, for two of these questions, at least one faculty member selected multiple responses. As the results in Table 2 indicate, the faculty members surveyed responded that the majority of capstone courses, that use "live" projects, are a single semester in length. This is somewhat surprising, since much of the current research (presented in the Introduction section) indicates that capstone courses are typically a two-semester series. The results in Table 2 also indicated that these capstone courses, that use "live" projects are always/usually taught by the same professor, typically assign 4-5 students per group and do not have a designated budget for the course. 


\section{Research Question 3}

In order to answer the third research question (If you use "live" projects in your capstone course, how do you solicit local companies' involvement?), the survey instrument posed the open-ended question "If you answered 'yes' to using 'live' projects, please briefly explain the process you use to solicit local companies' involvement?"

Seventeen of the twenty faculty members who use "live" projects responded to this question. A variety of responses were collected; many responses provided several sources for "live" projects. The majority of the responses $(71 \%)$ indicated that the process of finding "live" projects fell on the faculty member. As one faculty member stated "I normally email organizations or see if the college has received any calls for needing help." In their responses, other faculty indicated that they solicit "live" projects from their own personal contacts; in addition, they contact departments within the institution and outside businesses.

Many responses (41\%) also indicated that students participated in bringing "live" projects into the classroom. In some cases students were required to solicit "live" projects, while in other cases, students were simply asked to help to identify such projects. As one faculty member stated, "we don't solicit employers' participation; students must select a project that applies to their current employment." Responses indicated that students solicit "live" projects from their employers, family members and personal contacts.

Other responses indicated alternative sources including the use of advisory boards and the Internet to solicit "live" projects. As one faculty member stated, we "obtain from contacts, advisory board, LinkedIn".

\section{CONCLUSIONS}

The rapid developments in Computer Information Systems in the marketplace continue to drive the need for students to be proficient and up to date with skills that go beyond traditional CIS skills. As a result, educational institutions with Computer Information Systems and other computer-related programs of study need to design courses that reflect these changes as they prepare students to enter the job market. Not incorporating these changes in a CIS program can lead to students who are not competitive in the marketplace. The capstone course in a CIS program provides an excellent opportunity for students to learn multi-disciplinary skills that will make them more competitive in the marketplace.

As presented in the Research Results section, of the 30 faculty members surveyed from different computing programs throughout the United States, all of the programs include a capstone course in their curriculum. Furthermore, an overwhelming majority (69\%) of these capstone courses are using "live" projects. This indicates that institutions realize the benefits that "live" projects in a capstone course provide to: students, the community, faculty, the administration, the program and the university.

According to the Research Results, capstone courses are typically a single semester in length and are normally always taught by the same professor. These results are somewhat surprising, since, existing research shows that capstone courses are typically two semesters in length. Typically $4-5$ students are assigned to a given project. The course does not normally have a designated budget.

Unfortunately, the majority of the time, the task of soliciting these "live" projects falls on the faculty member teaching the course. In addition to the preparation and teaching of the course, the faculty member solicits projects from their own personal contacts, departments throughout the university and outside businesses. Many times, students also lead a role in soliciting projects from their employers, family members and personal contacts.

Based on the information collected from this study and the current research available, the authors plan to expand this study by examining ways to motivate students, beyond simply using "live" projects. We plan to examine what techniques are used to motivate students to perform at their best - to not procrastinate so as to conduct adequate user-acceptance and quality assurance testing, end-user training and some degree of system support with final fixes/modifications. 


\section{Issues in Information Systems}

Volume 14, Issue 2, pp.149-155, 2013

\section{REFERENCES}

1. ABET Computing Accreditation Commission. (2013). Criteria for accrediting computing programs. Retrieved April 1, 2013 at: http://www.abet.org/DisplayTemplates/DocsHandbook.aspx?id=3148

2. Abraham, S. (2006). The Anatomy of a Computer Information Systems (CIS) Capstone Course at a Small Midwestern University. In Proceedings of the Information Systems Educators Conference ISSN (Vol. 2713, pp 1-6). Retrieved March 27, 2013 from: http://www.proc.isecon.org/2006/2713/ISECON.2006.Abraham.pdf

3. Al-Huneidi, A., \& Schreurs, J. (2013). Constructivism Based Blended Learning in Higher Education. In Information Systems, E-learning, and Knowledge Management Research (pp. 581-591). Springer Berlin Heidelberg.

4. Brandon, D., Pruett, J., Wade, J. (2002). Experiences in Developing and Implementing a Capstone Course in Information Technology Management. Journal of Information Technology Education, 1(2), 91-102.

5. Descalu, S., Varol, Y., Harris, F. Westphal, B. (2005). Computer Science Capstone Course Senior Projects: From Project Idea to Prototype Implementation. In In Frontiers in Education, 2005. FIE'05. Proceedings 35th Annual Conference (pp. S3J-1). IEEE. Retrieved March 5, 2013 from: http://ieeexplore.ieee.org/xpl/login.jsp?tp=\&arnumber=1612293\&url=http $\% 3 \mathrm{~A} \% 2 \mathrm{~F} \% 2$ Fieeexplore.iee. $.0 \mathrm{~g} \% 2$ Fxpls\%2Fabs_all.jsp\%3Farnumber\%3D1612293

6. Erdem, A. (2013). The Constructivist Approach in Education. Journal of Education, (3), 61-77.

7. Feather-Gannon, S., Coppola, J., Daniels, C. K., Hale, N. L., Mosley, P., \& Taylor, A. (2013). The Evolution of Successful Service-Learning Courses in the Computing Curriculum: From Infancy to Innovation. The Journal of Computing Sciences in Colleges, 28, (6), 109-116.

8. Fordham, D. R., Bryant, S. M., \& Benke Jr, R. L. (2011). The evolution of an accounting information systems concentration: Concepts and an example. Review of Business Information Systems (RBIS), 1(3), 1-10.

9. Grandzol, J., Ochs, J. (2010). Bridging the Gap between Business and Information Systems ERP-based Curricula to Achieve Improved Business Process Learning Outcomes. Proceedings of DYNAA, 1(1). Retrieved March 16, 2013 from: http://99.140.126.9/dynaa2010/papers/004DY.pdf

10. Keller, S., Chan, C., \& Parker, C. (2012). Generic skills: do capstone courses deliver?. In HERDSA 2010: Refereed papers from the 33rd HERDSA Annual International Conference, (pp. 383-393). HERDSA. Retrieved March 15, 2013 from: http://dro.deakin.edu.au/view/DU:30030404

11. Kenny, R. W. (1998). Reinventing Undergraduate Education: A Blueprint for America's Research Universities. Boyer Commission on Educating Undergraduates in the Research University; Carnegie Foundation for the Advancement of Teaching.

12. Kumar, A., Baker, K., \& Ahmed, I. (2004). Designing a Capstone Course for Information Systems: Challenges Faced and Lessons Learned. Issues in Information Systems V (1), 173-179.

13. Magner, D. (1990). Many Colleges Design Courses and Programs to Prepare Seniors to Live in the 'Real World'. Chronicle of Higher Education, 36(27). Retrieved March 29, 2013 from: http://www.eric.ed.gov/ERICWebPortal/search/detailmini.jsp? nfpb=true\& \&ERICExtSearch SearchValue 0 $=$ EJ405553\&ERICExtSearch SearchType 0=no\&accno=EJ405553

14. Neville, K. \& Adam, F. (2003). Integrating theory and practice in education with business games. Informing Science Journal, 6, 61-73. Retrieved April 1, 2013 from http://inform.nu/Articles/Vol6/v6p061-073.pdf

15. Rakes, G. (1996). Using the Internet as a Tool in Resource Based Learning Environment. Educational Technology, 6(2), 52-69.

16. Reinicke, B., Janicki, T., \& Geber, J. (2012). Implementing an Integrated Curriculum with an Iterative Process to Support a Capstone Course in Information Systems. In Proceedings of the Information Systems Educators Conference ISSN (Vol. 2167, p. 1435). Retrieved March 27, 2013 from: http://proc.isecon.org/2012/pdf/1924.pdf

17. Reinicke, B., \& Janicki, T. (2010). Increasing Active Learning and End-Client Interaction in the Systems Analysis and Design and Capstone Courses. Information Systems Education Journal, 8(40). 3-10.

18. Wright, K. (2010). Capstone Programming Courses Considered Harmful. Communication of the ACM, 53(4), $1-4$. 